\title{
The genetic diversity of native, stocked and hybrid populations of marble trout in the Soca river, Slovenia
}

\author{
P. BERREBI* $\uparrow$, M. POVZ $\ddagger$ D. JESENSEK§, G. CATTANEO-BERREBI $\dagger$ \\ \& A. J. CRIVELLI \\ $\dagger$ Laboratoire Génome et Populations, CNRS-UPR 9060, Université Montpellier II, cc63, Place Eugène Bataillon, \\ 34095 Montpellier Cedex 05, France, \$Fisheries Research Institute, Zupanciceva 9, 61000 Ljubljana, Slovenia, \\ $\S$ Anglers' Society of Tolmin, Modrej 26a, 65216 Most na Soci, Slovenia and $\uparrow$ Station biologique de la Tour du Valat, \\ Le Sambuc, 13200 Arles, France
}

\begin{abstract}
The marble trout (Salmo marmoratus) is an endangered species in Slovenia (and in Italy, Croatia and Albania) because of hybridization resulting from intensive stocking. Eleven populations of trout from the Soca river basin (Slovenia) were analysed using 31 presumptive enzyme loci. Three European control samples representing the main European genotypes of brown trout were also analysed. This analysis confirmed the existence of extensive hybridization in the main river, resulting in an equal mixture of alleles belonging to marble trout, and Danubian and Atlantic brown trout (Salmo trutta). Despite the high level of introgression observed in the main Soca River, nearly pure populations of marble trout were found in the headwaters of five tributaries. The five stations with pure marble trout will be the basis of a rehabilitation programme. Hardy-Weinberg and linkage disequilibria were observed and hypotheses are discussed to explain this. A scenario for the colonization of the Adriatic region is proposed.
\end{abstract}

Keywords: allozymes, conservation, hybridization, marble trout, Slovenia.

\section{Introduction}

Many species or populations of introduced Salmonidae have introgressed with or have replaced the indigenous populations both in Europe and North America (Leary et al., 1995).

Since the beginning of the twentieth century, brown trout Salmo trutta, from various sources, have been introduced into the geographical range of the marble trout. The marble trout Salmo marmoratus has a restricted geographical distribution in the Po basin of northern Italy and in the Adriatic basins of the former Yugoslavia and Albania (Povz, 1995). The first introductions in Slovenia took place in 1906 (Povz et al., 1996). Later, and until recent years, the official management of the rivers included extensive stocking with brown trout resulting in hybridization (Jesensek, 1994; Povz et al., 1996). In Slovenia, the characteristics of the

\footnotetext{
*Correspondence and present address: Laboratoire Ecosystèmes Lagunaires, CNRS-ERS 2011, Université Montpellier II, cc93, Place Eugène Bataillon, 34095 Montpellier Cedex 05, France.

E-mail: berrebi@crit.univ-montp2.fr
}

species, i.e. a very particular marbled colour and its size (it is the largest European salmonid after Hucho hucho, growing to more than a metre in length and exceeding $25 \mathrm{~kg}$ in weight) are threatened.

In this study we have examined the genetic structure of trout populations in the single Slovenian drainage that this species inhabits. This basin flows mainly in mountainous regions. It is composed of a large main course, the Soca River, which is the species reservoir, but also is the most heavily stocked with brown trout, and several small tributaries which are expected to have been stocked less and which are more suitable for inhabitation by small but pure marble trout populations.

Before the start of this study, only the population of marble trout in the Zadlascica River, a tributary of the Soca River, was considered to be pure on morphological criteria (Povz, 1995), and this has already been used as a source of wild breeding stock. In this tributary, the marble trout is characterized by the total absence of red spots which has been empirically considered to be a guarantee of nonintrogression, as first proposed by Sommani (1960).

Allozymes are one of the most studied types of markers in trout. Giuffra et al. (1996) described several 
diagnostic loci distinguishing the Italian marble trout from the Mediterranean and the domestic Atlantic forms of Salmo trutta. Italian reference samples can be used in this study for comparison.

This study will therefore add to our understanding of the history of the trout in Europe. The reconstruction of the phylogeny and the history of the settlement of the various forms of European trout remains largely hypothetical and often contradictory. Reticulate evolution may have occurred, owing to successive invasions and hybridization, compounding the difficulty in estimating the origin of each group.

At present, mitochondrial markers, and particularly the sequence of the D-loop, provide the clearest available description of subdivisions within species at a continental scale. Bernatchez et al. (1992) demonstrated the existence of five classes of D-loop haplotypes. Four of these genetic classes can occur in our study area. The Atlantic type (At) has entered Slovenia by human introductions. The Danube type (Da), unsurprisingly, occurs in the eastern two-thirds of the country and has been able to enter the Soca basin by transfers of a few kilometres (although river capture cannot be excluded). The Mediterranean type (Me) occurs naturally in the Po basin (Giuffra et al., 1994). The marmoratus type (Ma) is endemic to the northern Adriatic region. The fifth type, the Adriatic (Ad), occurs in southern Greece and Italy and on the islands of Corsica and Sardinia and has little chance of entering our study basin.

Our aims were: (i) to characterize the Soca basin populations in different locations (main course and small tributaries) in comparison with samples of S. trutta from the neighbouring Danube basin and with reference samples (Table 1); (ii) to assess genetically the extent of hybridization; (iii) to confirm whether the Zadlascica population is genetically pure; (iv) to look for additional pure populations by sampling several headwater streams, because some others are also separated downstream from the hybridization zone by impenetrable natural or artificial obstacles; and (v) to compare the results to the main hypotheses of invasion in the Mediterranean region.

\section{Materials and methods}

\section{Sampling}

A list is given in Table 1 of the characteristics of the 11 samples analysed from Slovenia. Three reference samples were also involved: (i) $S$. marmoratus from the Po basin (population hybridized with fish-farm forms of S. trutta); (ii) wild Mediterranean S. trutta from the Rhône watershed; and (iii) S. trutta of Atlantic origin from the Fontanelle commercial fish farm (southern France). The choice of the Atlantic and Mediterranean $S$. trutta reference samples stems from the allozymic studies of Krieg \& Guyomard (1985) and Poteaux et al. (1998) who determined the diagnostic loci. The sample of Italian S. marmoratus has been introgressed by the brown trout and is very small (six trout). It has nevertheless been used because it is very difficult to find pure marble trout populations in Italy and because this sample remains suitable to compare the marble alleles of the Italian sample with the expected ones of Slovenian populations. A total of 396 trout were analysed.

The locations of the sampling sites in Slovenia, including the Soca and Danube drainages are shown in Fig. 1. The first basin is represented by two samples of the main course of the Soca River (Volarja 1 and 2) representing the central large population suspected to be heavily introgressed, and seven samples from small tributaries where pure marble trout populations should be found.

Table 1 General characteristics of the 14 samples of trout analysed

\begin{tabular}{|c|c|c|c|c|c|}
\hline Station & Abbrev. & Dates & Basin & $N$ & Types \\
\hline 1 Volarja 1 & Vol. 1 & November 1993 & Soca & 29 & Hybrids \\
\hline 1 Volarja 2 & Vol. 2 & June 1994 & Soca & 30 & Hybrids \\
\hline 3 Baca & Baca & November 1993 & Soca & 32 & Hybrids \\
\hline 4 Lipovscek & Lipov. & June 1994 & Soca & 29 & marmoratus \\
\hline 5 Huda Grapa & Huda & June 1994 & Soca & 24 & marmoratus \\
\hline 7 Zadlascica & Zadla. & November 1993 & Soca & 28 & marmoratus \\
\hline 8 Trebuscica & Trebu. & November 1993 & Soca & 31 & marmoratus \\
\hline 9 Iscica & Iscica & November 1993 & Danube & 29 & Hybrids \\
\hline 10 Bistrica & Bist. & June 1994 & Danube & 30 & Hybrids \\
\hline 11 Tagliamento & Tagl. & March 1994 & Po & 6 & Hybrids \\
\hline 12 Fontaine & Font. & July 1994 & Rhône & 30 & Mediterranean \\
\hline
\end{tabular}


Fig. 1 Location of the Slovenian sampling sites of trout populations.

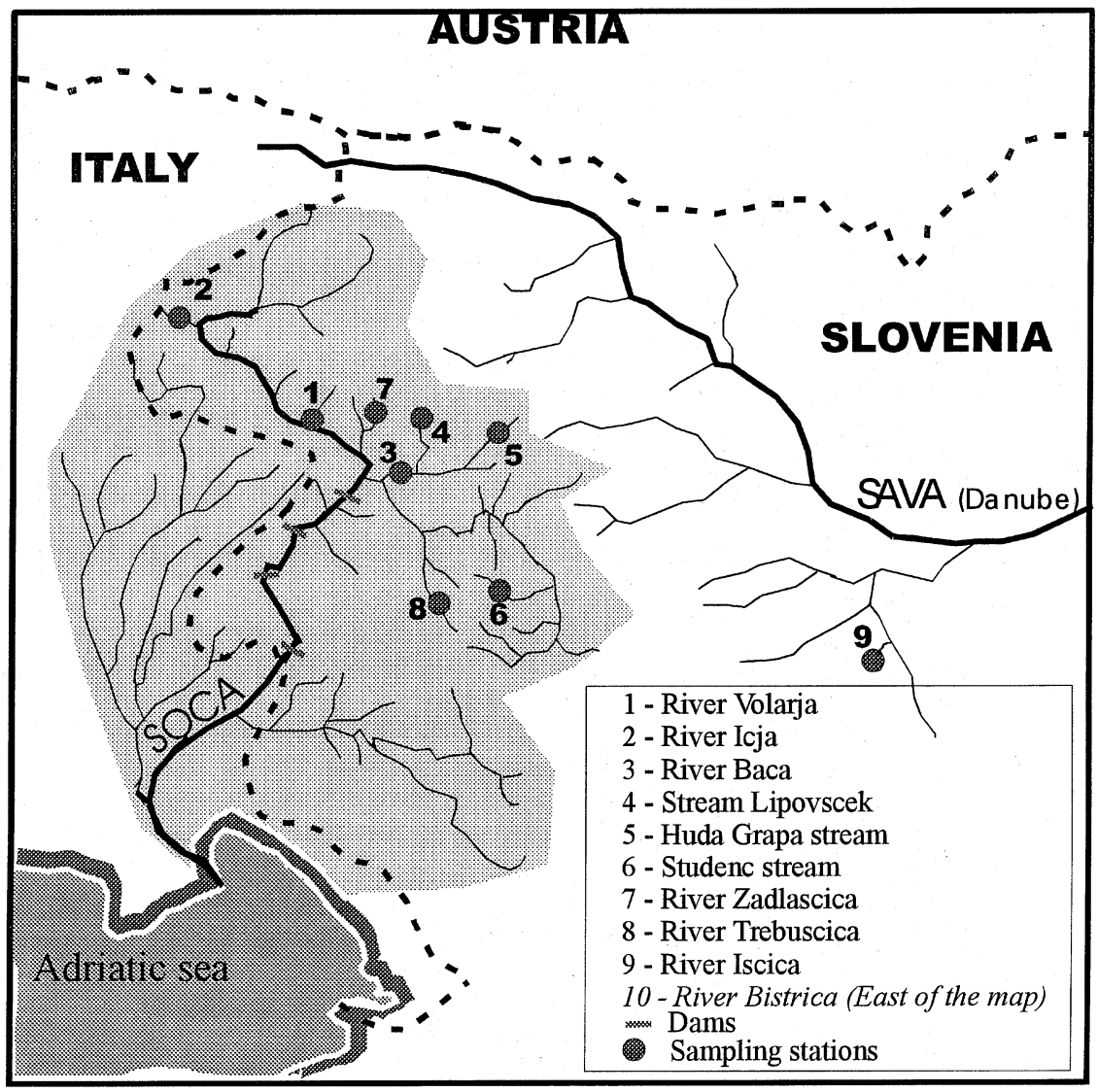

The 330 Slovenian trout analysed (subadults and adults) were captured by electric fishing in November 1993 and June 1994, anaesthetized at the Tolmin hatchery and dissected. About $1 \mathrm{~g}$ of muscle and liver, the eyes and a variable quantity of blood were taken from each fish. The first three organs were frozen immediately in liquid nitrogen, the blood was centrifuged and the serum and blood cells frozen separately. Blood was not collected from most of the samples in 1993, so data for the locus $T F^{*}$ are incomplete.

The allozyme analyses revealed 15 enzyme systems encoded by 31 presumptive loci. The biochemical method used for electrophoresis of proteins on a horizontal starch gel was that of Pasteur et al. (1987) as modified by Beaudou (1993).

\section{Statistical analyses}

1 Allele frequencies and heterozygosity ( $H$ the unbiased expected heterozygosity of Nei (1978)) were calculated using GENETIX software (Belkhir et al., 1998).

2 Correspondence analyses were conducted following their adaptation to allozyme data by She et al. (1987). This method, considered here as a test for the initial classification of the populations, is based on the following coding for alleles: $0=$ allele absent from the individual; 1 =present in heterozygote form; and $2=$ present in homozygote form. BIOMECO software was used for this analysis (Lebreton et al., 1990).

3 Tests of random mating genetic equilibria were of two types.

(i) Hardy-Weinberg equilibrium was measured by the parameter $F_{\text {IS }}$ (Wright, 1951) as estimated by the $f$-value of Weir \& Cockerham (1984). The significance of the $f$-values was estimated by permutation tests $(1000$ permutations) using the GENETIX software (see Berrebi \& Valiushok, 1998).

(ii) Linkage disequilibrium was measured using GENETIX, and using Cockerham \& Weir's (1979) coefficient of gametic disequilibrium for each pair of loci $\left(D_{i j}\right)$. The significance of the linkage disequilibrium was calculated using a permutation method.

These tests are considered as signs of hybridization (Waples \& Smouse, 1990), but this interpretation must be considered carefully because such disequilibria have also been observed in trout populations free of introgression (Aurelle \& Berrebi, 1998).

4 The introgression frequency was calculated as the proportion of totally diagnostic alleles belonging to each of the three taxa in each sample. These diagnostic alleles, 
observed only in the taxon they mark, have been recorded from allozyme analyses dealing with $S$. trutta (Krieg \& Guyomard, 1985; Poteaux \& Berrebi, 1997) and S. marmoratus (Giuffra, 1992). However, no allozymic diagnostic locus has been found that distinguishes between the Mediterranean and the Danubian brown trout samples. Osinov \& Bernatchez (1996) have confirmed this: allozymes are inefficient, whereas the mitochondrial marker (PCR-RFLP of the control region) can distinguish between the Danube and Mediterranean forms.

As we have no mitochondrial data from our samples, we regard the hybridization observed in the Soca main watercourse as resulting from artificial introductions of fish of Atlantic and Danube origins (the most probable hypothesis, given the proximity of the Danube). Only the Fontaine sample will be considered here as being Mediterranean.

The strictly diagnostic alleles (five for $S$. marmoratus, two for Danube $S$. trutta and two for Atlantic S. trutta) allowed us to estimate the degree of involvement of the three taxa in each sample. This estimate was based on the hypothesis that the diagnostic alleles of one taxon never occur in the other taxa. The data of Giuffra (1992) and Giuffra et al. (1996) largely confirm this hypothesis. The introgression frequency was equal to the mean frequency of marble trout alleles at the diagnostic loci in the sample in question, calculated as follows. An initial estimate consisted of measuring the proportion of marmoratus and non-marmoratus forms by calculating the mean frequencies of the diagnostic alleles at the $A A T-1^{*}, L D H-5^{*}, S O D^{*}$ and $T F^{*}$ loci. Then, among the 'non-marmoratus' forms, the relative percentage of Atlantic trutta/Danube trutta was calculated from the mean frequencies at the $L D H-5^{*}$ and $T F^{*}$ loci. This method of calculation had to be used because overall, $S$. marmoratus is the taxon that is most genetically distant from the others (Nei's genetic distance between the taxa Atlantic trutta and marmoratus in this study: $0.133 \leq D \leq 0.141$; between the taxa Danube/Mediterranean trutta and marmoratus: $0.098 \leq D \leq 0.138$; between the two trutta forms $D=0.1)$.

\section{Results}

\section{Frequencies and heterozygosity}

Allele frequencies and unbiased estimates of heterozygosity (Nei, 1978) are provided in Table 2.

Some populations (Zadlascica, Trebuscica, Studenc, Lipovscek and Huda Grapa) have a very low heterozygosity $(0.000<H<0.016)$ similar to that of wild Mediterranean headwater populations of $S$. trutta, of which the 'Fontaine' sample $(H=0.007)$ is a representative.

Other populations had a much greater heterozygosity, close to that of strains of Atlantic fish-farm S. trutta $(H>0.1$, Krieg \& Guyomard (1985)) such as the 'Fontanelle' sample $(H=0.118)$. These included the samples from Tagliamento in Italy, Ucja and Bistrica with moderate values $(0.047<H<0.091)$, and Iscica, Baca and Volarja (1 and 2) with higher values $(0.102<H<0.119)$.

\section{Correspondence analyses}

An initial correspondence analysis revealed the existence of three main groups (not shown here): (i) Atlantic S. trutta; (ii) Danube/Mediterranean S. trutta; and (iii) S. marmoratus. The Mediterranean and Danube forms cannot, however, be separated by their allozymes. Figure 2 shows a few of the samples selected to simplify the picture: the Atlantic, Danubian and Mediterranean samples have been used as references, and only the Zadlascica and Trebuscuca samples represent the pure marmoratus form, and the Volarja 1 sample represents the hybridized Soca population. The first two axes of the analysis account for $40.13 \%$ of the total inertia. Different symbols distinguish those individuals belonging to each sample. Three genetic groupings are clearly distinguishable.

The multidimensional analysis identified those alleles that are characteristic of each of the taxa that were studied.

The marmoratus taxon is characterized by the alleles $A A T-1 * 130$ and *180, LDH-5*120, SOD*50 and $T F^{*} 75$; the Danubian/Mediterranean taxon by $L D H$ $5^{*} 100$ and $T F^{*} 102$; the Atlantic taxon by $L D H-5^{*} 90$ and $T F^{*} 100$. This is the basis of the estimates of the introgression frequencies in the hybrid population analysed below.

\section{Introgression frequencies}

Table 3 summarizes the estimated proportions of genes belonging to the three taxa occurring in each sample. The samples with the lowest heterozygosity were either of pure S. marmoratus (Lipovscek and Huda Grapa), with low introgression frequencies (Trebuscica, Studenc), or Mediterranean S. trutta (Fontaine). The Trebuscica river sample had some alleles typical of brown trout: $A A T-1^{*} 100$ at a frequency of 0.02 and $L D H-5^{*} 100$ at a frequency of 0.04 . The Studenc river population had the $S O D-1^{*} 100$ allele, that is also characteristic of brown trout, at a frequency of 0.02 .

$H$ was also low in the Zadlascica population. This sample had the $A A T-1 * 100$ allele, diagnostic of brown 
Table 2 Allele frequencies and unbiased heterozygosity of trout populations following Nei (1978). Monomorphic loci are not presented

\begin{tabular}{|c|c|c|c|c|c|c|c|c|c|c|c|c|c|c|}
\hline & Vol. 1 & Vol. 2 & Ucja & Baca & Lipov. & Huda & Stud. & Zadla. & Trebu. & Iscica & Bist. & Tagl. & on & $\mathrm{Pis}$ \\
\hline$A A T-$ & 27 & 30 & 35 & 30 & 29 & 24 & 33 & 28 & 30 & 23 & 30 & 6 & 30 & 30 \\
\hline 100 & 0.44 & 0.68 & 0.10 & 0.70 & 0.00 & 0.00 & 0.00 & 0.02 & 0.02 & 0.89 & 0.97 & 0.25 & 1.00 & 0.95 \\
\hline 130 & 0.44 & 0.18 & 0.14 & 0.22 & 0.48 & 1.00 & 1.00 & 0.98 & 0.78 & 0.11 & 0.03 & 0.42 & 0.00 & 0.05 \\
\hline 180 & 0.11 & 0.13 & 0.76 & 0.08 & 0.52 & 0.00 & 0.00 & 0.00 & 0.20 & 0.00 & 0.00 & 0.33 & 0.00 & 0.00 \\
\hline$A A T-4^{*}$ & 29 & 30 & 35 & 28 & 29 & 18 & 33 & 26 & 28 & 27 & 30 & 6 & 30 & 30 \\
\hline 65 & 0.03 & 0.10 & 0.01 & 0.16 & 0.00 & 0.00 & 0.00 & 0.00 & 0.00 & 0.20 & 0.13 & 0.00 & 0.00 & 0.30 \\
\hline 80 & 0.00 & 0.02 & 0.00 & 0.00 & 0.00 & 0.00 & 0.00 & 0.00 & 0.00 & 0.00 & 0.28 & 0.00 & 0.00 & 0.00 \\
\hline 100 & 0.97 & 0.88 & 0.99 & 0.84 & 1.00 & 1.00 & 1.00 & 0.98 & 1.00 & 0.80 & 0.58 & 1.00 & 1.00 & 0.70 \\
\hline 110 & 0.00 & 0.00 & 0.00 & 0.00 & 0.00 & 0.00 & 0.00 & 0.02 & 0.00 & 0.00 & 0.00 & 0.00 & 0.00 & 0.00 \\
\hline$C K-1^{*}$ & 27 & 30 & 35 & 31 & 29 & 24 & 33 & 28 & 26 & 23 & 30 & 6 & 30 & 30 \\
\hline 100 & 1.00 & 0.97 & 1.00 & 0.90 & 1.00 & 1.00 & 1.00 & 1.00 & 1.00 & 1.00 & 1.00 & 1.00 & 1.00 & 0.80 \\
\hline 125 & 0.00 & 0.03 & 0.00 & 0.10 & 0.00 & 0.00 & 0.00 & 0.00 & 0.00 & 0.00 & 0.00 & 0.00 & 0.00 & 0.20 \\
\hline$C K-3^{*}$ & 29 & 30 & 35 & 32 & 29 & 24 & 33 & 28 & 30 & 29 & 30 & 6 & 30 & 30 \\
\hline 87 & 0.00 & 0.00 & 0.00 & 0.00 & 0.00 & 0.00 & 0.00 & 0.00 & 0.00 & 0.00 & 0.05 & 0.00 & 0.02 & 0.00 \\
\hline 90 & 0.00 & 0.00 & 0.00 & 0.00 & 0.00 & 0.00 & 0.00 & 0.00 & 0.00 & 0.02 & 0.00 & 0.00 & 0.00 & 0.00 \\
\hline 100 & 1.00 & 1.00 & 1.00 & 1.00 & 1.00 & 1.00 & 1.00 & 1.00 & 1.00 & 0.98 & 0.95 & 1.00 & 0.98 & 1.00 \\
\hline$F B P-$ & 24 & 30 & 34 & 20 & 29 & 18 & 33 & 26 & 26 & 24 & 30 & 6 & 30 & 30 \\
\hline null & 0.00 & 0.00 & 0.06 & 0.00 & 0.00 & 0.00 & 0.00 & 0.00 & 0.00 & 0.00 & 0.00 & 0.00 & 0.00 & 0.00 \\
\hline 100 & 0.73 & 0.85 & 0.94 & 0.90 & 1.00 & 1.00 & 1.00 & 1.00 & 1.00 & 0.75 & 0.27 & 1.00 & 0.03 & 0.73 \\
\hline 150 & 0.27 & 0.15 & 0.00 & 0.10 & 0.00 & 0.00 & 0.00 & 0.00 & 0.00 & 0.25 & 0.73 & 0.00 & 0.97 & 0.27 \\
\hline$F H-1^{*}$ & 29 & 28 & 35 & 32 & 29 & 18 & 33 & 26 & 28 & 22 & 29 & 6 & 30 & 30 \\
\hline 100 & 0.78 & 0.95 & 1.00 & 0.91 & 1.00 & 1.00 & 1.00 & 1.00 & 1.00 & 0.59 & 0.81 & 1.00 & 1.00 & 0.42 \\
\hline 135 & 0.22 & 0.05 & 0.00 & 0.09 & 0.00 & 0.00 & 0.00 & 0.00 & 0.00 & 0.41 & 0.19 & 0.00 & 0.00 & 0.58 \\
\hline G3PDH-2* & 27 & 30 & 35 & 28 & 29 & 24 & 33 & 28 & 30 & 20 & 30 & 6 & 30 & 30 \\
\hline 50 & 0.00 & 0.00 & 0.00 & 0.00 & 0.00 & 0.00 & 0.00 & 0.00 & 0.00 & 0.20 & 0.00 & 0.00 & 0.00 & 0.22 \\
\hline 75 & 0.00 & 0.00 & 0.00 & 0.02 & 0.00 & 0.00 & 0.00 & 0.00 & 0.00 & 0.00 & 0.00 & 0.00 & 0.00 & 0.00 \\
\hline 100 & 1.00 & 1.00 & 1.00 & 0.98 & 1.00 & 1.00 & 1.00 & 1.00 & 1.00 & 0.80 & 1.00 & 1.00 & 1.00 & 0.78 \\
\hline$G P I-$ & 27 & 3 & 3. & 3 & 29 & 24 & 3. & 2 & 30 & 20 & 30 & 6 & 30 & 30 \\
\hline 100 & 1.00 & 1.00 & 1.00 & 1.00 & 1.00 & 1.00 & 1.00 & 1.00 & 1.00 & 1.00 & 1.00 & 1.00 & 0.98 & 0.98 \\
\hline 200 & 0.00 & 0.00 & 0.00 & 0.00 & 0.00 & 0.00 & 0.00 & 0.00 & 0.00 & 0.00 & 0.00 & 0.00 & 0.02 & 0.02 \\
\hline$G P I-3^{*}$ & 27 & 30 & 35 & 30 & 29 & 24 & 33 & 28 & 30 & 19 & 30 & 6 & 30 & 30 \\
\hline 100 & 0.96 & 1.00 & 1.00 & 0.88 & 1.00 & 1.00 & 1.00 & 1.00 & 1.00 & 1.00 & 1.00 & 1.00 & 1.00 & 0.98 \\
\hline 106 & 0 & 0.00 & 0.00 & 0.0 & 0.00 & 0.00 & 0.00 & 0.0 & 0.00 & 0.00 & 0.00 & 0.00 & 0.00 & 0.02 \\
\hline 108 & 0.04 & 0.00 & 0.00 & 0.12 & 0.00 & 0.00 & 0.00 & 0.00 & 0.00 & 0.00 & 0.00 & 0.00 & 0.00 & 0.00 \\
\hline$L D H-5^{*}$ & 25 & 30 & 34 & 32 & 29 & 24 & 33 & 26 & 28 & 27 & 30 & 6 & 30 & 30 \\
\hline 90 & 0.3 & 0.40 & 0.1 & 0.3 & 0.0 & 0.00 & 0.00 & 0.0 & 0.00 & 0.7 & 0.25 & 0.00 & 0.00 & 0.97 \\
\hline 100 & 0. & 0.23 & 0.50 & 0.3 & 0.0 & 0.00 & 0.00 & 0.9 & 0.04 & 0.2 & 0.75 & 0.50 & 1.00 & 0.03 \\
\hline 120 & 0.28 & 0.37 & 0.37 & 0.25 & 1.00 & 1.00 & 1.00 & 0.04 & 0.96 & 0.02 & 0.00 & 0.50 & 0.00 & 0.00 \\
\hline$M D H-2^{*}$ & 2 & 3 & 3 & 3 & 29 & 18 & 33 & 2 & 28 & 27 & 30 & 6 & 30 & 29 \\
\hline 100 & 0.90 & 0.93 & 0.96 & 0.9 & 1.00 & 1.00 & 1.00 & 1.00 & 1.00 & 0.81 & 0.90 & 1.00 & 1.00 & 0.66 \\
\hline 200 & 0.10 & 0.07 & 0.04 & 0.03 & 0.00 & 0.00 & 0.00 & 0.00 & 0.00 & 0.19 & 0.10 & 0.00 & 0.00 & 0.34 \\
\hline$M D H-3^{*}$ & 26 & 30 & 35 & 31 & 29 & 24 & 33 & 28 & 30 & 22 & 30 & 6 & 30 & 30 \\
\hline 75 & 0.15 & 0.08 & 0.04 & 0.0 & 0.00 & 0.00 & 0.00 & 0.00 & 0.00 & 0.25 & 0.02 & 0.00 & 0.00 & 0.40 \\
\hline 100 & 0.85 & 0.92 & 0.96 & 0.98 & 1.00 & 1.00 & 1.00 & 1.00 & 1.00 & 0.75 & 0.98 & 1.00 & 1.00 & 0.60 \\
\hline$M P I^{*}$ & 29 & 30 & 35 & 32 & 28 & 18 & 33 & 26 & 28 & 27 & 30 & 6 & 30 & 30 \\
\hline 86 & 0.00 & 0.00 & 0.00 & 0.0 & 0.0 & $0.0 c$ & 0.11 & 0.0 & 0.0 & 0.0 & 0.00 & 0.0 & 0.00 & 0.00 \\
\hline 100 & & 0.92 & 0.9 & 0.8 & 1.00 & 1.00 & 0.89 & 1.00 & 1.00 & 0.76 & 0.83 & 1.00 & 0.95 & 0.57 \\
\hline 105 & 0.31 & 0.08 & 0.04 & 0.17 & 0.00 & 0.00 & 0.00 & 0.00 & 0.00 & 0.24 & 0.17 & 0.00 & 0.05 & 0.43 \\
\hline
\end{tabular}

(c) The Genetical Society of Great Britain, Heredity, 85, 277-287. 
Table 2 (Continued)

\begin{tabular}{|c|c|c|c|c|c|c|c|c|c|c|c|c|c|c|}
\hline & Vol. 1 & Vol. 2 & Ucja & Baca & Lipov. & Huda & Stud. & Zadla. & Trebu. & Iscica & Bist. & Tagl. & Font. & Pisc. \\
\hline 85 & 0.00 & 0.00 & 0.00 & 0.00 & 0.00 & 0.00 & 0.00 & 0.00 & 0.00 & 0.00 & 0.02 & 0.00 & 0.00 & 0.00 \\
\hline$S O D-1 *$ & 29 & 30 & 35 & 32 & 29 & 18 & 33 & 27 & 28 & 27 & 30 & 6 & 30 & 30 \\
\hline 50 & 0.41 & 0.48 & 0.77 & 0.39 & 1.00 & 1.00 & 0.98 & 1.00 & 1.00 & 0.00 & 0.00 & 0.92 & 0.00 & 0.00 \\
\hline$T F^{*}$ & 0 & 30 & 34 & 0 & 29 & 24 & 33 & 0 & 5 & 0 & 28 & 0 & 29 & 30 \\
\hline 75 & NT & 0.58 & 0.74 & NT & 1.00 & 1.00 & 1.00 & NT & 1.00 & NT & 0.00 & NT & 0.00 & 0.00 \\
\hline 98 & NT & 0.00 & 0.00 & NT & 0.00 & 0.00 & 0.00 & NT & 0.00 & NT & 0.04 & NT & 0.00 & 0.00 \\
\hline 100 & NT & 0.33 & 0.10 & NT & 0.00 & 0.00 & 0.00 & NT & 0.00 & NT & 0.27 & NT & 0.00 & 1.00 \\
\hline 102 & NT & 0.08 & 0.16 & NT & 0.00 & 0.00 & 0.00 & NT & 0.00 & NT & 0.70 & NT & 1.00 & 0.00 \\
\hline
\end{tabular}

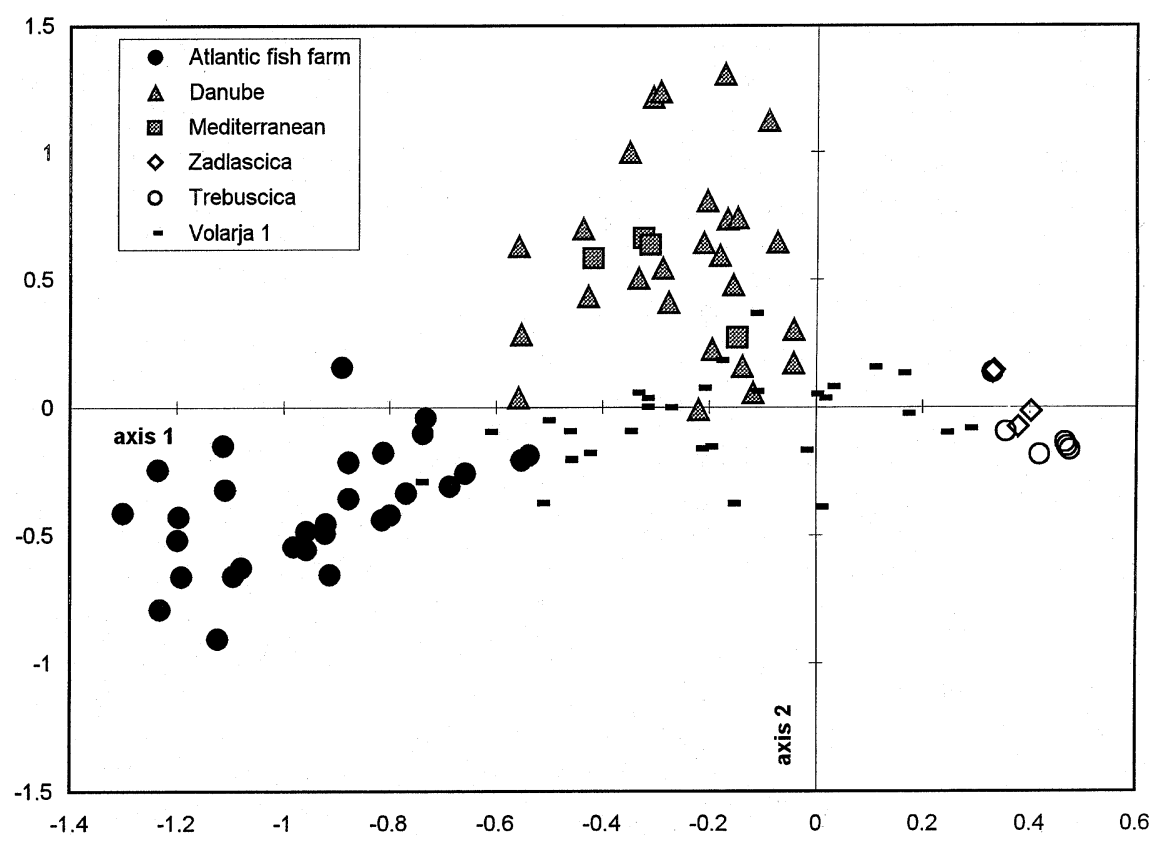

Fig. 2 Plot of individuals on axes 1 and 2 of the correspondence analysis (see text).

Table 3 Frequencies of alleles originating from the three genetic types of trout calculated for each sample. The $L D H-5^{*}$ locus was not used for the Zadlascica sample (see text)

\begin{tabular}{|c|c|c|c|c|c|c|c|c|c|c|c|c|c|c|}
\hline & Vol. 1 & Vol. 2 & Ucja & Baca & Lipov. & Huda & Stud. & Zadla. & Trebu. & Iscica & Bist. & Tagl. & Font. & Pisc. \\
\hline \multicolumn{15}{|l|}{ marmoratus } \\
\hline & 0.41 & 0.43 & 0.69 & 0.31 & 1.00 & 1.00 & 0.99 & 0.99 & 0.99 & 0.04 & 0.01 & 0.72 & 0.00 & 0.01 \\
\hline \multicolumn{15}{|l|}{ Danubian } \\
\hline & 0.28 & 0.17 & 0.23 & 0.36 & 0.00 & 0.00 & 0.00 & 0.00 & 0.01 & 0.22 & 0.73 & 0.28 & 1.00 & 0.02 \\
\hline \multicolumn{15}{|l|}{ Atlantic } \\
\hline
\end{tabular}


trout, at a frequency of 0.02 , and especially the $\mathrm{LDH}$ $5 * 100$ allele, that is diagnostic of the Mediterranean/ Danubian brown trout, at a frequency of 0.96 .

As a first step of the analysis, the stations Trebuscica, Studenc and Huda Grapa can be considered as highly representative of ancestral populations of the Soca basin, despite the occurrence of foreign diagnostic alleles at a very low frequency. The case of the Zadlascica population will be discussed further.

The other samples showed variable, but usually large, introgression frequencies. This was correlated with a high heterozygosity resulting from artificial mixing (introduction and hybridization), and probably the use of high-heterozygosity pisciculture strains. The population from the Ucja station was still mainly marmoratus $(\approx 70 \%)$, whereas the stations closer to the river Soca (stations Volarja 1 and 2 and Baca) had almost equal proportions of alleles from the three genetic types, showing the highly hybridized state of the central trout stock in the zone most subject to angling.

The Danube stations also had highly mixed populations, but with the retention of largely Danube characteristics at Bistrica $(72 \%)$ and an Atlantic dominance $(74 \%)$ at the Iscica station, evidence of intensive stocking of commercial stocks of international origin.

The results of the study of population disequilibria are summarized in Tables 4 and 5.

\section{Hardy-Weinberg disequilibria}

There was no heterozygote deficit in the four samples of S. marmoratus, which was to be expected given such low
Table 4 Value and significance of $F_{\text {IS }}$ in trout populations estimated for each sample
Table 5 Value and significance of linkage disequilibria in trout populations, estimated for each sample

\begin{tabular}{|c|c|c|c|c|}
\hline Station & Type or origin & $F_{\text {IS }}$ & $P<(\%)$ & Significance \\
\hline 1 Volarja 1 & Hybrid a-m-d & -0.100 & 95.8 & NS \\
\hline 1 Volarja 2 & Hybrid a-m-d & 0.179 & 0.2 & $* *$ \\
\hline 2 Ucja & Hybrid a-m & 0.078 & 11.4 & NS \\
\hline 3 Baca & Hybrid a-m-d & 0.134 & 1.2 & $*$ \\
\hline 4 Lipovscek & Soca & 0.461 & 2.0 & $*$ \\
\hline 5 Huda Grapa & Soca & No polymorphism & & - \\
\hline 6 Studenc & Soca & -0.089 & 100 & NS \\
\hline 7 Zadlascica & Soca & -0.010 & 100 & NS \\
\hline 8 Trebuscica & Soca & 0.133 & 9.8 & NS \\
\hline 9 Iscica & Atlantic & 0.124 & 3.9 & $*$ \\
\hline 10 Bistrica & Danube & 0.159 & 1.0 & $* *$ \\
\hline 11 Tagliamento & Po & -0.190 & 85.6 & NS \\
\hline 12 Fontaine & Mediterranean & 0.275 & 6.4 & NS \\
\hline 13 Fontanelle & Atlantic & 0.137 & 1.2 & $*$ \\
\hline
\end{tabular}

Hybrid composition: a, Atlantic; m, marble; d, Danube.

$* P<0.05 ; * * P<0.01 ; * * * P<0.001$.

\begin{tabular}{llccccl}
\hline Station & \multicolumn{1}{c}{ Type } & $\mathrm{H}$ & $*$ & $* *$ & $* * *$ & Linkage level \\
\hline Volarja 1 & Hybrid a-m-d & 0.119 & 0 & 0 & 0 & Absent \\
Volarja 2 & Hybrid a-m-d & 0.106 & 4 & 3 & 0 & High \\
Ucja & Hybrid a-m & 0.070 & 6 & 1 & 3 & Very high \\
Baca & Hybrid a-m-d & 0.102 & 1 & 2 & 0 & Low \\
Lipovscek & Soca & 0.016 & - & - & - & $(H$ very low $)$ \\
Huda Grapa & Soca & 0.000 & - & - & - & $(H$ very low $)$ \\
Studenc & Soca & 0.007 & - & - & - & $(H$ very low $)$ \\
Zadlascica & Soca & 0.005 & - & - & - & $(H$ very low $)$ \\
Trebuscica & Soca & 0.014 & - & - & - & $(H$ very low $)$ \\
Iscica & Atlantic & 0.107 & 2 & 1 & 0 & Low \\
Bistrica & Danube & 0.091 & 2 & 2 & 0 & Low \\
Tagliamento & Po & 0.047 & - & - & - & $(H$ very low $)$ \\
Fontaine & Mediterranean & 0.007 & - & - & - & $(H$ very low $)$ \\
Fontanelle & Atlantic & 0.118 & 1 & 0 & 0 & Very low \\
\hline
\end{tabular}

Hybrid composition: a, Atlantic; m, marble; d, Danube.

${ }^{*} P<0.05 ; * * P<0.01 ; * * * P<0.001$ 
heterozygosity. There was however, one exception: the Lipovscek sample.

A deficit of heterozygotes was detected in two samples from the Danube (Bistrica: $P<0.01$ and Iscica: $P<0.04)$, which is probably related to their hybrid composition.

The panmixia disequilibria detected at the highly mixed stations were irregular, with a highly significant $F_{\text {IS }}$ at Volarja 2 in $1994(P<0.002)$ and a lower value in the Baca sample $(P<0.02)$.

\section{Linkage disequilibria}

Linkage disequilibria showed significant values, but on pairs of loci that varied from one sample to another. No permanent linkage is therefore detectable. Table 5 shows that the Volarja 2 and especially Ucja samples had more significant disequilibria compared to the possible number of tests $(7 / 55$ and $10 / 38$, respectively) although comparing the intensity of linkage disequilibrium between populations having different allele frequencies is impossible. Paradoxically, Volarja 1 had no linkage disequilibrium despite the possibility of conducting many tests $(0 / 45)$. Several other samples showed linkage disequilibria mostly recorded together with deficits of heterozygotes (Bistrica: 4/55; Iscica: 3/45; Baca: 3/65).

\section{Discussion}

\section{Population disequilibria}

The existence of linkage and Hardy-Weinberg disequilibria is a sign that at least a part of the population is not yet stabilized, undoubtedly as a result of human interference, or of genomic incompatibility caused by hybrid breakdown, which could compromise it in the future. It is known that Hardy-Weinberg equilibrium is regained in a single generation of random mating whereas linkage disequilibria decay exponentially, depending on recombination (Waples \& Smouse, 1990). As already observed in European trout (Poteaux \& Berrebi, 1997; Berrebi et al., 2000), the heterozygosity values are instructive, because in populations that have been greatly modified by man they are correlated with the degree of introgression of exotic genes into the wild genome when the latter have a low heterozygosity.

The Slovenian samples can be classified according to the existence, level and nature of disequilibria.

1 Equilibrium in $F_{\mathrm{IS}}$ and linkage parameters but very low heterozygosity (Zadlascica, Trebuscica, Studenc, Lipovscek and Huda Grapa): in these cases no disequilibria are measurable because of the absence of polymorphism, i.e. a low power to detect disequilibria.
According to their allelic composition in diagnostic loci, these populations are mostly composed of S. marmoratus alleles (99-100\%). The observed alleles in this kind of population probably represent the common alleles of the ancestral marmoratus population. 2 Equilibrium in $F_{\text {IS }}$ and linkage parameters but moderately high heterozygosity (Iscica, Baca, Bistrica and Volarja-1): the genetic equilibrium of the populations can be confirmed. This is a surprising finding for the Baca and Volarja-1 samples, as they represent the most hybridized populations. It can be explained by the hypothesis of 'no recent stocking' (November 1993), whereas the sample Volarja-2 (see below) would be restocked before sampling (June 1994).

3 Linkage disequilibrium only, moderately high heterozygosity (Ucja): this case can be explained by recent introductions, but not in the present year, because it is known that linkage disequilibria can last several years, reducing by half with each generation, whereas HardyWeinberg disequilibria can be absorbed within one generation.

4 Disequilibria with $F_{\text {IS }}$ and linkage parameters, moderately high heterozygosity (Volarja-2): this is close to the main course of the Soca and this sample is therefore representative of the main reservoir inhabitants, where hybridization is more intense. These disequilibria are expected in a population subject to frequent introductions. The classical Wahlund effect, assortative mating and genomic incompatibilities between the three hybridizing taxa (Leary et al., 1995) might cause such disequilibria.

There are a number of special cases that require further comments.

$1 \mathrm{LDH}-5^{*}$ and red spots in the Zadlascica population: this station is populated by marble trout, until now considered by river managers as being entirely pure. So this population was used for the first attempts at creating stocks of marble trout for restocking at Tolmin (Povz, 1995). One of the reasons for this opinion was the typical marmoratus appearance and the absence of red spots along the flanks. However, trout belonging to other samples that are clearly recognized as pure (or nearly pure) marmoratus in the present study all have a series of pinkish red spots near the lateral line. The only population not to have these is the Zadlascica population, though this population is unusual because $96 \%$ of the alleles of the $\mathrm{LDH}-5^{*}$ marker are characteristic of the Mediterranean or Danubian trutta taxa. This feature, in a population isolated for several tens or hundreds of thousands of years by insurmountable waterfalls, is probably the result of drift related to drastic reductions of population size.

Two hypotheses can be proposed to explain this observation. This genetic anomaly can stem from 
(i) an ancestral polymorphism, the founding Adriatic populations possessing both 100 and 120 alleles and (ii) a relic of ancient hybridization between the former resident form (probably Mediterranean S. trutta) and the invasive form ( $S$. marmoratus). Under both hypotheses, genetic drift could easily have favoured a minority allele, including that responsible of the absence of red spots.

According to mitochondrial data (Apostolidis et al., 1996, 1997), the Mediterranean and marbled forms split from an ancestral local form. The two hypotheses could thus be considered to be very similar if we propose that the ancestral polymorphism might perhaps result from previous hybridization.

Nevertheless, we have shown that the pure marmoratus form can have red spots, and that this criterion, widely used by anglers to distinguish pure marmoratus from hybrids, is invalid.

$2 F_{\text {IS }}$ disequilibrium in pure marble trout populations: most of the pure (or almost pure) marmoratus samples shows an almost entire absence of enzyme polymorphism and so no genetic disequilibrium. Such low genetic diversity can be explained by the reduced size of the headwater population (Shaw et al., 1994).

However, $F_{\text {IS }}$ was estimated to be $0.46(P<0.05)$ in the Lipovscek river, which cannot be explained by introgression. Such a deficit of heterozygotes has already been observed in natural populations of brown trout using allozyme markers (Poteaux et al., 1998) and microsatellites (Aurelle \& Berrebi, 1998). These authors discussed the various possible causes of such natural deficits; we add the possibility, for very small populations, that the individuals captured could be related (Hansen et al., 1997).

3 Temporal genetic heterogeneity of the Volarja population: genetic differences in Volarja-1 and Volarja-2 samples separated by seven months are associated with changes in the mean percentage involvement of each of the three taxa, marmoratus, Danube trutta and Atlantic trutta (difference significant, $P<0.001$; see Table 3$)$. Only in Volarja-2 is $F_{\text {IS }}$ different from zero $(P<0.01)$ and linkage disequilibrium is high. This instability between November 1993 and June 1994 could have been caused (i) by human interference (e.g. recent restocking in 1994); in this case only repeated sampling in the future could provide clarification; or (ii) by seasonal factors related to migrations of an unknown nature, so that two samples taken from the same site at different seasons (here autumn and spring) would represent different parts of a heterogeneous population. As the Volarja tributary has a barrier preventing upstream migration less than a kilometre from its confluence, these supposed migrations would not be exchanges between the main river and the tributary, but rather upstream/ downstream movements of the immense hybrid population of the Soca.

\section{A palaeohistorical scenario}

Giuffra et al. (1996) gave two alternative hypotheses for the colonization of the Po, depending on the order of arrival of the two natural forms that occur (marble and Mediterranean), but they produced no decisive argument in favour of one or the other.

An important finding in our data was the strong presence of the $L D H-5^{*}(100)$ allele in the Zadlascica, an isolated headwater population. If we accept the second proposed hypothesis (hybridization following marble trout invasion) and use the argument adopted by Hamilton et al. (1989) suggesting the sequence of the colonization of the basin, the presence of Mediterranean alleles upstream and their absence downstream suggests that the marmoratus form arrived last. In the Po basin, marble trout occupy the lower and middle reaches of the northern tributaries, whereas Mediterranean trout occur in the headwaters of these tributaries (Sommani, 1960). This author showed that the rivers of the northern Adriatic were connected during marine regressions of greater than $100 \mathrm{~m}$. During such periods the Soca belonged to the same watershed as the Po and the history of colonization of the two rivers was probably the same. This allows us to extrapolate our hypothesis to the Po basin.

An alternative hypothesis is that there was a widespread formation of hybrids and that determining which arrived first is therefore impossible. However, the fact that only the headwaters of one river (the Zadlascica) barred by a waterfall of more than $20 \mathrm{~m}$ tall still contains alleles of the Mediterranean form suggests, but does not prove, that the hypothesis that trutta arrived before marmoratus is correct. It seems that in this basin, the invasion of the marmoratus form led to the total disappearance of the original occupant, except in the Zadlascica River. However, the differentiation of a genotype and the history of its settlement at any given site, which is a stage of expansion that can take a long time, must not be confused.

\section{Conclusion}

This allozyme analysis of Slovenian trout confirms suspicions of Sommani (1960), Jesensek (1994) and Povz et al. (1996) based on morphological observations, that the marble trout populations have been introgressed by brown trout. The present study provides further evidence for introgression, suggesting that two distinct forms of brown trout were involved: Danube brown 
trout resulting from transfers between drainages in former Yugoslavia, and Atlantic brown trout, perhaps from Austria and commercial strains. In this 'tripolar' hybridization, alleles of three origins occur in roughly equal proportions in the Soca central basin (i.e. Volarja samples) where sport fishing occurs.

This study has also demonstrated the existence of five stations in which the populations are pure (or almost pure) marmoratus. This finding permitted the creation of a pure marble strain for restocking obtained by mixing reproducers from several pure populations.

\section{Acknowledgements}

This study was funded by the Foundation of Tour du Valat and by a grant of WWF-International (Project 9E0073) awarded to Dr A.J. Crivelli. We would like to express special thanks to D. Aurelle, L. Bernatchez, C. Greig, J.L. Garcia-Marin, D. Hedgecock, C. Poteaux and V.K. Rashbrook for their valuable comments on earlier versions of the manuscript and to B. Britton for linguistic help. Samples were provided by the Fisheries Society of Tolmin (Slovenia), the Fédération de Pêche du Vaucluse (France), M. Specchi and E. Pizzul (Italy).

\section{References}

APOSTOLIDIS, A. P., KARAKOUSIS, Y. AND TRIANTAPHYLLIDIS, C. 1996. Genetic differentiation and phylogenetic relationships among Greek Salmo trutta L. (brown trout) populations as revealed by RFLP analysis of PCR amplified mitochondrial DNA segments. Heredity, 77, 608-618.

APOSTOLIDIS, A. P., TRIANTAPHYLLIDIS, C., KOUVATSI, A. AND ECONOMIDIS, P. S. 1997. Mitochondrial DNA sequence variation and phylogeography among Salmo trutta L. (Greek brown trout) populations. Mol. Ecol., 6, 531-542.

AURELle, D. AND BERREBI, P. 1998. Microsatellite markers and management of brown trout Salmo trutta fario populations in south-western France. Génét. Sél. Évol., 30, S75-S90.

BEAUdou, D. 1993. Impact des déversements de truites domestiques dans les populations naturelles de truites communes (Salmo trutta fario). Etude dynamique et génétique. Cas du bassin de l'Orb (Hérault). Thèse de l'Université de Montpellier II.

BELKHIR, K., BORSA, P., GOUDET, J., CHIKHI, L. AND BONHOMME, F. 1998. GENETIX, logiciel sous WindowsTM pour la génétique des populations. http://www.univ-montp2.fr/ $\sim$ genetix/genetix.htm. In: Laboratoire Génome et Populations, CNRS UPR 9060. Université Montpellier II, Montpellier, France.

BERNATCHEZ, L., GUYOMARD, R. AND BONHOMME, F. 1992. DNA sequence variation of the mitochondrial control region among geographically and morphologically remote European brown trout Salmo trutta populations. Mol Ecol., 1, 161-173.
BERREBI, P. AND VALIUSHOK, D. 1998. Genetic divergence among morphotypes of Lake Tana (Ethiopia) barbs. Biol. J. Linn. Soc., 64, 369-384.

BERREBI, P., POTEAUX, C., FISSIER, M. AND CATTANEO-BERREBI, G. 2000. Stocking impact and allozymic biodiversity in southern France Mediterranean brown trout (Salmo trutta). J. Fish Biol., 56, 949-960.

COCKerham, C. C. AND WEIR, B. S. 1979. Digenic descent measures for finite population. Genet. Res., 30, 121-147.

GIUFFRA, E. 1992. Identificazione genetica e filogenia delle populazioni di trota comune, Salmo trutta L., del bacino del Po. PhD Thesis, University of Torino, Italy.

GIUFFRA, E., BERNATCHEZ, L. AND GUYOMARD, R. 1994. Mitochondrial control region and protein coding gene sequence variation among phenotypic forms of brown trout Salmo trutta from northern Italy. Mol. Ecol., 3, 161-171.

GIUfFrA, E., GUYOMARD, R. AND FORNERIS, G. 1996. Phylogenetic relationships and introgression patterns between incipient parapatric species of Italian brown trout (Salmo trutta L. complex). Mol. Ecol., 5, 207-220.

HAMilton, K. E., FERGUSON, A., TAGgART, J. B., TOMASSON, T., WALKER, A. AND FAHY, E. 1989. Post-glacial colonisation of brown trout, Salmo trutta L. Ldh-5 as a phylogeographic marker locus. J. Fish Biol., 35, 651-664.

HANSEN, M. M., NEILSEN, E. E. AND MENSBERG, K.-L. D. 1997. The problem of sampling families rather than populations: relatedness among individuals in samples of juvenile brown trout Salmo trutta L. Mol. Ecol., 6, 469-474.

JESENSEK, D. 1994. Artificial propagation of marble trout (Salmo marmoratus Cuvier 1817) in the Fisheries Society of Tolmin. In: Kirchhofer, A. and Hefti, D. (eds) Symposium on the Conservation of Endangered Freshwater Fish in Europe, p. 24. University of Bern, SSHL, FOEFL, Bern, Switzerland.

KRIEG, F. AND GUYOMARD, R. 1985. Population genetics of French brown trout (Salmo trutta L.): large geographical differentiation of wild populations and high similarity of domesticated stocks. Génét. Sél. Évol., 17, 225-242.

LEARY, R. F., ALLENDORF, F. W. AND SAGE, G. K. 1995. Hybridization and introgression between introduced and native fish. Am. Fish Soc. Symp., 15, 91-101.

LEBRETON, J.-D., ROUX, M., BANCO, G. AND BACOU, A. M. 1990. BIOMECO (Biometry-Ecology), version 3.9. Statistical ecology software for PC and compatible. C.E.F.E., Montpellier, France.

NEI, M. 1978. Estimation of average heterozygosity and genetic distance from a small number of individuals. Genetics, 89, 583-590.

OSINOV, A. G. AND BERNATCHEZ, L. 1996. 'Atlantic' and 'Danubian' phylogenetic groupings of brown trout Salmo trutta complex: genetic divergence, evolution, and conservation. J. Ichthyol., 36, 723-746.

PASteur, N., PASTeur, G., Bonhomme, F., CATAlan, J. AND BRITTON-DAVIDIAN, J. 1987. Manuel de Génétique par Électrophorèse des Protéines. Lavoisier, Paris.

POTEAUX, C. AND BERREBI, P. 1997. Intégrité génomique et repeuplements chez la truite commune du versant méditerranéen. Bull. Français Pêche Pisciculture, 344/345, 309-322. 
poteaux, C., BeAudou, D. AND Berrebi, P. 1998. Temporal variations of genetic introgression in stocked brown trout (Salmo trutta L.) populations. J. Fish Biol., 53, 701-713.

POvz, M. 1995. Status of freshwater fishes in the Adriatic catchment of Slovenia. Biol. Conserv., 72, 171-177.

POVZ, M., JESENSEK, D., BERREBI, P. AND CRIVELLI, A. J. 1996. The Marble Trout, Salmo trutta marmoratus, Cuvier 1817 in the Soca River Basin, Slovenia. Tour du Valat Publication. Le Sambuc, France.

SHAW, P. W., CARVALHO, G. R., MAGURRAN, A. E. AND SEGHERS, B. H. 1994. Factors affecting the distribution of genetic variability in the guppy, Poecilia reticulata. J. Fish Biol., 45, 875-888.

SHe, J. X., AUTEM, M., KotUlas, G., PASTEUR, N. AND BONHOMME, F. 1987. Multivariate analysis of genetic exchanges between Solea aegyptiaca and Solea senegalensis (Teleosts, Soleidae). Biol. J. Linn. Soc., 32, 357-371. sommani, E. 1960. Il Salmo marmoratus Cuv. sua origine e distribuzione nell'Italia settentrionale. Bolletino di Pesca, Piscicoltura e Idrobiologia, 15, 40-47.

WAPLES, R. S. AND SMOUSE, P. E. 1990. Gametic disequilibrium analysis as a means of identifying mixtures of salmon populations. Am. Fish Soc. Symp, 7, 439-458.

WEIR, B. S. AND COCKERHAM, C. C. 1984. Estimating $F$-statistics for the analysis of population structure. Evolution, 38, 1358-1370.

Wright, s. 1951. The genetical structure of populations. Ann. Eugen., 15, 323-354. 